\title{
Exploring the drivers of tensions in social innovation management in the context of social entrepreneurial teams
}

(Pre-print version - Paper accepted for publication in Management Decision)

\begin{abstract}
Purpose - This paper identifies tensions that are emerging in the invention and implementation of social innovation by social entrepreneurial teams and highlights elements that influence the type of tension encountered.
\end{abstract}

Design/methodology/approach - Four cases are selected theoretically, studied individually, and compared to one another to identify tensions and patterns of tensions.

Findings - The findings reveal the predominant tensions related to goals and identity during social innovation invention and those related to time and knowledge during social innovation implementation. The size of the entrepreneurial team, the nature of the social innovation, and the interest orientation - that is, the overlap between entrepreneurial team members and beneficiaries - are found to play a role in the type of tensions encountered and their content.

Research limitations/implications - The chosen research approach limits the generalisability of the research results. Replication in other settings and with other types of social innovation is therefore encouraged.

Originality/value - In contrast to most existing studies, this research focuses on nascent social innovation projects borne by teams. It proposes that social-business tensions are not necessarily predominant in social innovation management. It suggests the importance of interest orientation as an under-estimated factor in the study of social entrepreneurship. 


\section{Introduction}

The social innovation process is imbued with tensions. Indeed, many social innovations emerge from dissatisfactions with the status quo (Mulgan, 2012), which they address to contribute to the well-being of people, communities, and society (Dawson and Daniel, 2010). Social innovation is itself likely to generate tensions by transforming the market or institutionalized norms and values (Nicholls and Murdock, 2012). The collective dynamics cited by several scholars as being fundamental to the social innovation process (CajaibaSantana, 2014; Murray et al., 2010; Nicholls and Murdock, 2012) are by nature also a source of tensions (e.g., Forsyth, 2010). Yet, the literature mostly focuses on the management of such tensions with external stakeholders (Cajaiba-Santana, 2014), and it is rather silent on how social innovators manage these tensions internally.

To bridge this gap, this research investigates how teams manage social innovation in a social entrepreneurship setting. More precisely, this paper identifies tensions that emerge during the invention and implementation of social innovation by social entrepreneurial teams as well as the elements that influence the types of tension experienced.

Insights from paradox theory on organizational tensions are used to study and compare four nascent social entrepreneurial projects. The findings confirm that the two initial phases of social innovation management (i.e., inventing and implementing) are infused with tensions. Structural factors such as entrepreneurial team size, interest orientation, and the nature of the social innovation being implemented are shown to matter with regard to the type and the content of tensions facing social entrepreneurial teams.

The next section presents the theoretical background by briefly reviewing the literature on social innovation management and on tensions in social entrepreneurship. The study methods are then described, and findings are presented and discussed in the subsequent sections. Limitations, contributions, and managerial implications are finally put forward.

\section{Theoretical background}

Social innovation management and tensions 
Definitional issues have been central to the scholarly debate on social innovation (Dawson and Daniel, 2010; Tracey and Stott, 2017). In particular, the meaning of the 'social' qualification is extensively discussed as it is socially constructed and concerned with politics and ethics (Lawrence et al., 2014). This paper uses the widely cited definition of social innovation provided by Phills et al. (2008, p. 36): "a novel solution to a social problem that is more effective, efficient, sustainable, or just than existing solutions and for which the value created accrues primarily to society as a whole rather than private individuals." This definition allows social innovations to be either products or processes. It also encompasses the three different levels of social innovation that have been identified: 1) incremental innovation that seeks to address market failures more effectively; 2 ) institutional innovation that aims to reconfigure existing market structures for the generation of social value; and 3) disruptive innovation that aims to change cognitive frames and modify social systems (Nicholls and Murdock, 2012).

Various multi-stage approaches have been developed to describe the social innovation process (Mulgan, 2006; Murray et al., 2010; Perrini et al., 2010). Most authors share Mulgan's (2006) approach in distinguishing at least three stages. First, the invention or ideation stage includes activities and sub-stages such as diagnosing a problem, understanding needs, and generating ideas for potential solutions (Mulgan, 2006; Murray et al., 2010). Second, the implementation or conversion of ideas stage entails prototyping and assessing an idea as well as sustaining it (Mulgan, 2012; Murray et al., 2010). Mulgan (2012) stresses that the invention and implementation stages of social innovation are interrelated as social innovators often wish to implement their innovation rapidly and then modify their initial approach depending on the feedback they receive. Third, the diffusion and scaling stage should ultimately result in systemic change (Mulgan, 2006; Murray et al., 2010; Perrini et al., 2010). A learning loop, in which innovations evolve by taking account of unexpected applications or circumstances may be added to these three stages (Mulgan, 2006).

Scholars have presented tensions - understood in this paper in its broad sense as "clash[es] of ideas or principles or actions and [...] the discomfort that may arise as a result" (Stohl and Cheney, 2001, p. 353-354) - as being central factors throughout the social innovation process. First, tensions form the basis for social innovation and are therefore crucial prior to 
and during the invention phase (Nicholls and Murdock, 2012). Indeed, social innovation often stems from dissatisfactions with the status quo that are caused by new knowledge, new demands, and new needs (Mulgan, 2012). Next, social innovation implementation creates tensions by challenging this status quo for established stakeholders (CajaibaSantana, 2014; Nicholls and Murdock, 2012). Tensions may also arise in social innovation due to its collective nature and to the socially constructed nature of both the targeted social need and its suggested solution (Nicholls and Murdock, 2012). Hence, political maneuvering is inevitably at work (Lawrence et al., 2014). However, a more detailed account is currently lacking with regard to the types of tensions that may emerge during the social innovation process. In addition, little is known of the context - in terms of process stage and structural elements - in which the tensions are likely to arise. To fill this gap, the following section focuses on social entrepreneurship, a setting often associated with social innovation (Phillips et al., 2015).

\section{Tensions in social entrepreneurship}

In the same way as entrepreneurship is commonly characterized by innovation (Audretsch, 2012), social entrepreneurship is often presented either as a process bearing social innovation (Bhatt and Altinay, 2013; Perrini et al., 2010; Phillips et al., 2015; Tracey and Stott, 2017) or a process requiring social innovation as a precondition for its success (Roy and Karna, 2015). Social entrepreneurship is generally seen as combining a social mission with market activities (Defourny and Nyssens, 2010). This inherently hybrid character imbues social entrepreneurship with tensions (Besharov and Smith, 2014).

Paradox theory is a metatheoretical perspective that has proved useful in analysing tensions in complex organizational contexts, such as hybrid organizations and social enterprises in particular (Lewis and Smith, 2014; Smith et al., 2013). It rests on the premises that organizations are inherently filled with tensions due to the interplay of complex and dynamic systems, and that these tensions are both cognitively and socially constructed as paradoxical when actors polarize elements (Lewis and Smith, 2014). Paradoxes are thus one specific type of tensions (Michaud, 2013) that are defined as "contradictory yet interrelated elements that exist simultaneously and persist over time" (Smith and Lewis, 2011, p. 382). Following this definition, Smith and Lewis (2011) catalog four categories of organizational 
tensions that are distinguished by the locus of tension. Performing tensions are linked to organizational goals and arise from the plurality of stakeholders and their potentially conflicting demands. Organizing tensions arise from divergent internal dynamics geared toward achieving a specific desired outcome. Belonging tensions emerge at the identity level. They comprise tensions between the individual and the collective and between competing values, roles, and memberships. Learning tensions deal with knowledge and emerge from changes in dynamic systems (Smith and Lewis, 2011).

Based on Smith and Lewis' (2011) categorization, Smith et al. (2013) document organizational tensions for social ventures. The social entrepreneurship literature likely addresses performing tensions the most because of the inherent duality of goals, reflected in discussions about metrics (Mertens and Marée, 2012), paradoxical outcomes (Jay, 2013), and mission drift (Jones, 2007; Pache and Santos, 2010), among others. In social enterprises, organizing tensions may concern human resource management policies such as hiring and socialization processes (Battilana and Dorado, 2010) and choice of legal form (Child et al., 2015). Belonging tensions may occur at the team level, between members of a social entrepreneurial team that identify with different logics (Dufays and Huybrechts, 2016), or at the individual level (Wry and York, 2017), possibly resulting in tensions about external identity (Nelson et al., 2016). Learning tensions particularly arise from diverging time horizons (Smith et al., 2013). They include tensions regarding social enterprise scaling, which may jeopardize the social mission, especially if the latter is closely related to the local context (Smith and Stevens, 2010).

The literature, however, lacks information for identifying the situations in which these tensions emerge, both in terms of organizational configuration and life cycle. Figure 1 builds on Smith et al. (2013) and illustrates the identified tensions with regard to the various stages of the social innovation process.

\section{[INSERT FIGURE 1 ABOUT HERE]}

Tensions in social entrepreneurship and in social innovation management have mostly been studied for established ventures (Lettice and Parekh, 2010; Smith et al., 2013). The rare 
accounts pertaining to nascent social entrepreneurship are based on paradox perceptions of solo entrepreneurs (Wry and York, 2017). Yet, several scholars have emphasized collective dynamics as a fundamental component of the social innovation and social entrepreneurship processes (Cajaiba-Santana, 2014; Dufays and Huybrechts, 2014; Huarng and Yu, 2011; Murray et al., 2010; Nicholls and Murdock, 2012). To fill these gaps, this paper investigates the tensions stemming from the internal dynamics of social entrepreneurial teams during invention and implementation stages, which correspond to social innovation nascency.

\section{Methods}

An exploratory perspective was adopted through a qualitative and abductive research approach (Patton, 2002). A multiple-case study method was selected because it is particularly suited to analyse context and process (Flyvbjerg, 2011) in situations in which the investigator has little or no control over the context (Yin, 2003). Further, notwithstanding the deep understanding of complex issues they provide (Yin, 2003), case studies enable theory-building through identification of differences and similarities within a group of cases on the one hand and through a logic of replication and confrontation with existing literature on the other hand (Eisenhardt, 1989; Eisenhardt and Graebner, 2007; Yin, 2003).

Projects in an early phase were identified from applications to a programme supporting financially nascent social entrepreneurship. Theoretical sampling was conducted to observe the variability across cases along theoretically relevant dimensions that had potential to extend theory and/or to eliminate alternative explanations (Eisenhardt and Graebner, 2007; Yin, 2003). Four cases were selected along two dimensions: nature of social innovation and entrepreneurial team size (see Table I). The former dimension is chosen because incremental and institutional social innovations differ in focus and objective (Nicholls and Murdock, 2012) and are therefore likely to capture different types of tensions. Team size is selected because of its demonstrated relationship with tensions. Indeed, the more team members, the more likely heterogeneity of meanings will be present regarding what to do and how it should be done (Eisenhardt and Schoonhoven, 1990). Also, larger teams require more coordination, which may give rise to additional tensions (Amason and Sapienza, 1997). Our sample includes two small teams (PermaGuild and Youth@Work had respectively two and three members at the time of data collection) and two larger teams (five and 17 
members, respectively, for InterGen and IndepMag). The real names of the entrepreneurial projects and team members are not disclosed to maintain anonymity.

\section{[INSERT TABLE I ABOUT HERE]}

Empirical data were gathered through in-depth interviews with multiple informants (see Table II) and document analysis between 2012 and 2015. The interviews were composed of open-ended questions structured around three main topics: the informant's life story, the entrepreneurial project's inception, and the entrepreneurial team and its functioning. The interviews lasted between 51 and 88 minutes, and they were recorded and transcribed. Additional data were collected from respondents by mail or by phone if some issues were unclear during interview transcription. Documents included the application to the support programme, presentation documents, newspaper clippings, and local TV channels' videos.

Two teams also provided access to minutes from internal meetings. Finally, I drafted memos during and directly after the interviews, as well as during transcription, to keep track of impressions and analytical insights.

\section{[INSERT TABLE II ABOUT HERE]}

Data analysis followed advice by Eisenhardt (1989), Eisenhardt and Graebner (2007), and Yin (2003) to first conduct individual case analyses and then identify patterns of similarity and differences in a cross-case analysis to generate theoretical insights (for a detailed account of the analysis process, see Table III). Using Smith and Lewis' (2011) categorization of organizational tensions as an analytical framework, I first coded interview transcripts and documents by highlighting excerpts that dealt with any of the four loci of tensions: outcomes, means, identity, and knowledge. This approach allowed the creation of a corpus per locus, with some excerpts listed simultaneously in two corpuses. Tension identification was achieved following Andriopoulos and Lewis's (2009) approach. Within each corpus, mentions of tensions by respondents were identified through language indicators such as: tension, friction, yet, but, while simultaneously, whereas, on the contrary. Contradictory statements within the same corpus were also sought. Whenever possible, the source(s) and the eventual resolution of the identified tensions were highlighted to further contextualize 
the data (Andriopoulos and Gotsi, 2017). For this paper, only tensions relating to the internal functioning of the team were kept. The cross-case analysis was conducted along the categories used for the sampling strategy: team size and social innovation nature. During analysis, interest orientation appeared as a third relevant category for comparison. This category relates to the extent to which the social aim is oriented toward the mutual interest of team members or toward the general interest (Gui, 1991). In other words, it pertains to the degree to which only team members benefit from the social innovation they want to implement against exclusively external beneficiaries (see Figure 2 for a tentative mapping of the studied cases against ideal-typical cases).

[INSERT TABLE III ABOUT HERE]

[INSERT FIGURE 2 ABOUT HERE]

\section{Findings}

The findings reveal the presence of tensions in each case studied in the four loci identified by Smith and Lewis (2011) - i.e. goals, means, identity, and time and knowledge. In the following text, tensions are distinguished that emerged during the first two phases of the social innovation process: invention and implementation. This section aims to illustrate the types of tensions experienced during specific (sub-)stages and to identify their sources.

\section{Invention}

The sub-stage of understanding the social need to address appears crucial for capturing the tensions in the social entrepreneurial team in subsequent (sub-)stages. Indeed, identifying a need and generating ideas entail defining who will benefit from the innovation and how to maximize this benefit. These issues are closely related to team members' identity and desired outcomes.

Different (sub-groups of) team members are likely to understand the social need, hence conceive the needed social innovation, in different ways based on their sets of preferences, their familiarity with the social logic, their past socializations, and/or eventually their profession. Therefore, tensions in this early stage may be closely tied to identity and values, which is particularly true in the larger teams. At IndepMag, the professional identity and its 
underlying values define how individual team members position themselves with regard to the scope of the social need - that is, independence in media - and how to address it. Journalists consider the financial aspect of conducting independent investigation as the need to be addressed by a high-quality magazine, whereas graphical designers see the social need much more broadly. They see independence as also coming from the choice of tools and materials, requiring the use of open-source software. As expressed by one team member,

There is a logic of graphical designers and a logic of journalists. [...] For graphical designers, it is very straightforward that the aesthetic dimension of the magazine is political, and that the choice to use open-source software may justify some mistakes in the magazine. [...] On the contrary, journalists find those mistakes inadmissible in a high-quality magazine. (IM4)

The heterogeneity among team members in terms of their proximity to the identified social need is another identity-based source of performing tensions. Although presenting themselves as a team of parents, InterGen members internally distinguish between those who benefit directly from the social innovation (i.e., parents with a handicapped child) and the others. The former consider themselves more legitimate, particularly in the invention phase, as they are the ones who experience the social need. When diverging perceptions of what solutions were best for the handicapped children created a conflict, the members with no handicapped child had no say on the desired outcome. Their opinion on the project was no longer deemed relevant by most parents.

The scope of institutional social innovations is at the heart of performing tensions during the idea generation stage. IndepMag experienced tensions due to antagonistic solutions to different identified social needs. Aiming to provide fair pay for investigative work while constraining financial income to sales to guarantee independency and autonomy prevents IndepMag from granting broad and cheap access to the press, which some team members value. The team thus had to rank the social needs they wanted to address and agree on collective preferences. For the Youth@Work team, such tensions arose with regard to scaling and diffusion intentions. While team member YW2 aims to conceive a replicable model for other social needs, other members focus on the specific need for fair internships. 
Divergence within the team seems to be based on how strongly individual team members have experienced the identified social need. One team member stated the following:

For me, the most important [thing] is that it can be replicated. YW1, he had a real anger for the interns' situation because he said it was unacceptable. He [...] is very committed to the situation of interns. I want to prove that the economy can change from the inside. And I would like to replicate this model for other beneficiaries. I'm not sure this is the case for the other cofounders. (YW2)

\section{Implementation}

Learning and organizing tensions appear to prevail once the social need is identified and potential ideas of how to address it are generated. During the implementation phase of social innovation, learning tensions seem to occur at the prototyping and idea evaluation sub-stages, while organizing tension particularly emerges when a structure to sustain the innovation is being sought. An important source of learning tensions during idea evaluation lies in the long-term outcome of a social innovation - that is, whether the social innovation as implemented will correctly meet the identified social need in an enduring way. This source of tension is especially likely in the case of institutional innovation because its final impact on the market is difficult to assess at this early stage and it is likely to require more time to reach its full potential in addressing the social need. For example, IndepMag needs to become a larger player in the field to 'change the rules of the game in newspaper industry' (IM3). It may also happen for incremental innovations, when the social need targets 'silent' beneficiaries, such as in the case of InterGen. Indeed, parents cannot be certain of what is best for their handicapped children's future.

The idea evaluation sub-stage at Youth@Work reveals the emergence of tensions stemming from the external knowledge gained by the team. The crowdsourcing method used to elaborate the criteria for the labelling activity and the acquired experience with regard to the readiness of enterprises - that is, their paying customers - to conform to these criteria provided contradictory information to the team members. If the criteria established from crowdsourcing with stakeholders are too costly for an enterprise to achieve, Youth@Work is likely to fail in its commercial dimension as no label will be sold. On the other hand, if they 
conform too much to the knowledge they gained from enterprises about their willingness to change their internship policy, Youth@Work is likely to miss the social aim of their social innovation and to fail to lastingly transform the market.

Two elements appear to crystallize most organizing tensions: commitment to the effective implementation and governance mechanisms to structure collective decision-making. Entrepreneurs are often passionate about the social innovation they want to implement, and they are eager to move ahead as fast as possible (Mulgan, 2006; Mulgan, 2012). However, their involvement is regularly subject to the lack of personal income. Like traditional entrepreneurs, many social entrepreneurs choose to commit only part of their time to the nascent entrepreneurial project, while working part-time for another revenuemaking job (Folta et al., 2010). This unbalanced involvement generated tensions with regard to fair allocation of work in the two small teams (PermaGuild and Youth@Work) and with regard to democratic decision making in the case of IndepMag. One team member describes how tensions arise as follows:

There was rather a very active core and a less active group but very emotionally involved. And one of the opinions that I defend somehow, it is that those who are doing things decide. And if we are at a meeting and some members could not come, the group who is present can decide. And that created tensions because some people who are less active sometimes said 'But no, we have not been consulted. This is not democratic.' (IM2)

Larger teams face organizing tensions when dealing with the paradox between consensus/democratic decision-making and control. At IndepMag, the horizontal decisionmaking structure conflicts with the hierarchy that is supposedly needed for the production of the magazine through the editing functions. This organizing tension superimposes on belonging tensions. Indeed, the rotating chief-editor role is always occupied by a journalist, which structurally attributes more power to this sub-group. At InterGen, the divide between parents and non-parents is institutionalized. Even though the team claims to be striving for consensus and 'being in the same boat' (IG5), parents are given more voting power than non-parents in decisions. This power imbalance based on identity is justified by the 
closeness to the social need and the wish to avoid mission drift in the long run. This justification is also reflected in the selection of the legal form:

So the foundation legal form was justified by [...] having an entity that would guarantee the project in the long run, because nonprofits are too democratic. [...] One day or another, there may be a majority at the General assembly or at the Board of directors who decide that, in the end, mixing old people and handicapped people is not really a good idea. [...] So we wanted to secure the project, especially fearing that handicapped people would one day be ejected from the facility, because they are not revenuegenerating enough. (IG1)

\section{Discussion}

Although existing literature typically explains tensions in social entrepreneurship and social innovation management around the tension between commercial and social logics (Battilana and Lee, 2014; Smith et al., 2013), this section centers the discussion around the three factors selected for case comparison, that is, team size, nature of social innovation, and interest orientation. Propositions for theoretical development on each of these dimensions are formulated. Consequences on the social innovation process are then examined. Figure 3 illustrates the main points of the discussion.

\section{[INSERT FIGURE 3 ABOUT HERE]}

The findings confirm that entrepreneurial team size is associated with tensions, particularly performing and organizing tensions. Extant literature shows that larger teams tend to include a broader variety of skills, knowledge, and attitudes, and they therefore exhibit higher cognitive heterogeneity, resulting in more numerous interpretations of courses of action (Amason and Sapienza, 1997; Eisenhardt and Schoonhoven, 1990). The findings empirically confirm Wry and York's (2017) propositions that diverging identity elements - in this case, professions and closeness to social need for IndepMag and InterGen, respectively - may also create such variation, particularly in the perception of the social need to be addressed. This situation results in differing interpretations of what the social character of social innovation ought to be, highlighting the socially constructed nature of social 
innovation (Lawrence et al., 2014, Nicholls and Murdock, 2012). Hence, the socially constructed nature of social innovation will likely reveal more performing tensions around circumscribing what the social need is and what solutions to develop (invention stage) within larger entrepreneurial teams.

Proposition 1a: During the invention stage of the social innovation process, larger social entrepreneurial teams are more likely to face performing tensions concerning the social logic of the innovation.

Among the organizing tensions occurring during implementation, those originating in team member involvement concern the fair distribution of effort in smaller teams, whereas in larger teams they involve decision-making and governance structure issues. This difference can be explained by the higher affective and economic impact of disengagement - or lower involvement - of a member of a smaller team (Francis and Sandberg, 2000). Larger teams are more likely to be able to continue working at the same pace if one member defects temporarily, as exemplified by IndepMag. Also, peer pressure against free-riding behavior is likely to be stronger in smaller teams, particularly when they are characterized by strong ties between members (Backes-Gellner et al., 2015). In contrast, larger teams face tensions in balancing efficiency (commercial logic), focus on their social mission (social logic), and democratic decision-making (social logic) in their governance.

Proposition 1b: During the implementation stage of the social innovation process, smaller social entrepreneurial teams are more likely to face organizing tensions relating to member involvement located concerning the commercial logic of the innovation, whereas larger teams are more likely to face organizing tensions between the social and commercial logics of the innovation.

With regard to the nature of social innovation, findings show that teams working on institutional innovation experience performing tensions during the invention stage, especially concerning the required hierarchization of social needs. This happens because the teams aim to transform markets, which is therefore likely to modify the social structure in indirect and possibly unintended ways (Nicholls and Murdock, 2012). Consequently, they often touch upon several social issues, which raises power issues (Heiskala, 2007). The 
political discussions within IndepMag to define what 'independency' and 'fair' mean to the team, and in particular with regard to the use of open source software, illustrate the diversity of social issues the team needs to handle in transforming the press market by setting new standards of production. During the idea assessment sub-stage of implementation, the larger number of stakeholders and the more uncertain outcomes of institutional innovation (Heiskala, 2007; Nicholls and Murdock, 2012) are more likely to generate learning tensions. The discrepancy between the crowdsourced criteria for labelling and the experience with businesses of Youth@Work is a typical example of such conflicting knowledge issues.

Proposition 2: During the invention stage of the social innovation process, social entrepreneurial teams aiming at institutional innovation are more likely to face performing tensions concerning the social logic of the innovation.

The analysis uncovered that interest orientation is a dimension that matters with regard to tensions, yet it is not mentioned in the extant literature. The invention and implementation phases appear to be more integrated by teams that have both a mutual interest at stake and a general interest (a classification of social enterprises suggested by Gui (1991)). Because of the superimposition of the producer/investor role with the beneficiary role that characterizes organizations driven by mutual interest (Mertens, 1999), team members seem further motivated to simultaneously embrace both the social and the commercial dimensions needed for implementation. They therefore account for the inherent hybridity of social innovation earlier in the invention process. This situation probably explains why they seem to face stronger tensions with regard to understanding the need to be addressed, as illustrated by the need to rank social needs at IndepMag, and constructing the social character of the innovation. Mutual interests of members are not perfectly aligned given the diverging experience of the social need, provoking differences in interpretation of what the social nature of the innovation means in terms of goals, means, identities, and time horizon. Such differences are illustrated in the case of InterGen when parents of handicapped children who benefit directly - thus mutual interest - do not agree on how to address a seemingly shared social need. During implementation, differing degrees of mutual interest or diverging mutual interests within a team may create power imbalances and 
tensions that need to be solved through organizational governance (e.g., selection of legal form for InterGen, specific decision-making processes for IndepMag).

Proposition 3a: The invention and implementation stages of the social innovation process are more strongly integrated for social entrepreneurial teams pursuing both mutual and general interests.

Proposition 3b: During the invention stage of the social innovation process, social entrepreneurial teams pursuing both mutual and general interests are more likely to face tensions concerning the social logic of the innovation rather than between the social and commercial logics.

Finally, the findings confirm that the processes of social innovation invention and implementation are strongly interrelated (Anderson et al., 2014; Mulgan, 2012). At the least, this integration depends on the interest orientation and the nature of the social innovation. As already mentioned, when team members have both a producer role and a beneficiary role, like at InterGen, feedback from the idea assessment sub-stage of implementation is likely to come earlier in the process; it may even be simulateneous with the need understanding sub-stage of invention. However, it may also delay implementation because of discussions to tailor the innovation to the needs of individual team members, suggesting a great overlap between the two phases (Mulgan, 2006). Second, feedback loops from the implementation to the invention phase are likely to be more numerous and to have a greater scope for teams focussing on institutional social innovation. Indeed, the likely unexpected effects generated by market transformation need to be taken into account by the entrepreneurial team in adapting the initial idea, as Youth@Work experienced with the feedback from enterprises.

\section{Limitations, contributions, and implications}

Despite careful research design, this study is not without limitations. First, limits inherent to the case study method need to be acknowledged, and caution is particularly needed in generalizing the results to all types of organizations carrying social innovation. Social entrepreneurship is generally considered as an ideal-typical case of process that generates social innovation, but other tensions might be observed in other processes such as social intrapreneurship (Ritchie et al., 2015; Tracey and Stott, 2017). Next, this paper does not 
look at the consequences of tensions, such as turnover, creativity, and performance, which are left for future research.

Despite these limitations, this study contributes to social innovation management and social entrepreneurship literature in two main ways. First, the findings reveal some challenges facing nascent social entrepreneurs (Renko, 2013) by identifying potential tensions they may have to contend with when entrepreneuring in a team. Whereas most literature has looked at interactions with the environment and/or tensions within established organizations (Battilana and Lee, 2014; Pache and Santos, 2010), this study examines interindividual interactions during the early phases of the process. In this regard, the study particularly shows that the social character of social innovation is a reservoir for tensions, a circumstance that has been underestimated in the literature so far. Indeed, this study deviates from the traditional focus on tensions caused by the social/commercial duality of social ventures (Battilana and Lee, 2014; Smith et al., 2013), as the findings do not show this duality to be at the core of most experienced tensions. Rather, many tensions are rooted in different understandings of the 'social' component of social innovation and its socially constructed nature (Cajaiba-Santana, 2014). This study stresses the diverging experiences of the social need and/or diverging identity elements, including differing closeness to the social need, as drivers of such tensions. As a consequence, it calls for research on hybrid organizations, and on social entrepreneurship in particular, to also focus on the distinct underlying logics rather than solely on the interaction between them.

Second, this paper adds to the literature by highlighting the potential of the distinction between mutual interest and general interest missions (Gui, 1991) to explain variation in tensions in social innovation management. So far, extant studies have only stressed that social innovators or social entrepreneurs often experience a social need directly or through a close relative before engaging in social innovation invention (Germak and Robinson, 2013; Lawrence et al., 2014; Yitshaki and Kropp, 2016). This paper also considers how they benefit from the social innovation after its implementation as it results in different types of tensions at both the invention and implementation stages of the process. By suggesting that this element should be considered as constitutive of personal identity that particularly matters in social innovation management and social entrepreneurship, this paper empirically 
extends the existing literature theorizing how role and personal identities shape how social entrepreneurs combine social and commercial logics (Wry and York, 2017).

For social entrepreneurs and accompanying structures, such as social innovation incubators, this study implies that inter-individual interactions in social entrepreneurial teams should be handled carefully. In particular, it helps teams anticipate some likely tensions depending on their size, the type of social innovation they pursue, and the relationship team members have to beneficiaries. It especially stresses the importance of collectively defining the social character of the need to be addressed and the solution they want to introduce early in the entrepreneurial process. Such clarification is likely to reduce inter-individual tensions and to ease the transition from social innovation invention to implementation. This study also implies that social entrepreneurial teams should reflect on the nature of the social innovation they would like to implement and their position with regard to its beneficiaries. The study also suggests that including some degree of mutual interest is likely to facilitate the integration of the social and commercial logics and accelerate the transition from invention to implementation through a greater overlap between idea generation and idea assessment.

Finally, this study implies that policy-makers may reduce potential tensions in social innovation management by better defining what constitutes the social character in social innovation, notably by determining sectors that are supported. However, they should be cautious in creating their definitions to avoid hampering creativity and the development of alternatives in sectors of activity that may not be officially considered relevant to social innovation.

\section{References}

Amason, A.C. and Sapienza, H.J. (1997), "The effects of top management team size and interaction norms on cognitive and affective conflict", Journal of Management, Vol. 23 No. 4, pp. 495-516.

Anderson, N., Potočnik, K. and Zhou, J. (2014), "Innovation and creativity in organizations", Journal of Management, Vol. 40 No. 5, pp. 1297-1333. 
Andriopoulos, C. and Gotsi, M. (2017), "Methods of paradox", in: Smith, W. K., Lewis, M. W., Jarzabkowski, P. and Langley, A. (Eds.), The Oxford Handbook of Organizational Paradox, Oxford University Press, Oxford, pp. 513-528.

Andriopoulos, C. and Lewis, M.W. (2009), "Exploitation-exploration tensions and organizational ambidexterity: Managing paradoxes of innovation", Organization Science, Vol. 20 No. 4, pp. 696-717.

Audretsch, D. (2012), "Entrepreneurship research", Management Decision, Vol. 50 No. 5, pp. 755-764.

Backes-Gellner, U., Werner, A. and Mohnen, A. (2015), "Effort provision in entrepreneurial teams: Effects of team size, free-riding and peer pressure", Journal of Business Economics, Vol. 85 No. 3, pp. 205-230.

Battilana, J. and Dorado, S. (2010), "Building sustainable hybrid organizations: The case of commercial microfinance organizations", Academy of Management Journal, Vol. 53 No. 6, pp. 1419-1440.

Battilana, J. and Lee, M. (2014), "Advancing research on hybrid organizing: Insights from the study of social enterprises", Academy of Management Annals, Vol. 8 No. 1, pp. $397-$ 441.

Besharov, M.L. and Smith, W.K. (2014), "Multiple logics within organizations: Explaining their varied nature and implications", Academy of Management Review, Vol. 39 No. 3, pp. 364-381.

Bhatt, P. and Altinay, L. (2013), "How social capital is leveraged in social innovations under resource constraints?", Management Decision, Vol. 51 No. 9, pp. 1772-1792.

Cajaiba-Santana, G. (2014), "Social innovation: Moving the field forward. A conceptual framework", Technological Forecasting and Social Change, Vol. 82 No., pp. 42-51.

Child, C., Witesman, E.M. and Braudt, D.B. (2015), "Sector choice: How fair trade entrepreneurs choose between nonprofit and for-profit forms", Nonprofit and Voluntary Sector Quarterly, Vol. 44 No. 4, pp. 832-851.

Dawson, P. and Daniel, L. (2010), "Understanding social innovation: A provisional framework", International Journal of Technology Management, Vol. 51 No. 1, pp. 921.

Defourny, J. and Nyssens, M. (2010), "Conceptions of social enterprise and social entrepreneurship in Europe and the United States: Convergences and divergences", Journal of Social Entrepreneurship, Vol. 1 No. 1, pp. 32-53.

Dufays, F. and Huybrechts, B. (2014), "Connecting the dots for social value: A review on social networks and social entrepreneurship", Journal of Social Entrepreneurship, Vol. 5 No. 2, pp. 214-237.

Dufays, F. and Huybrechts, B. (2016), "Where do hybrids come from? Entrepreneurial team heterogeneity as an avenue for the emergence of hybrid organizations", International Small Business Journal, Vol. 34 No. 6, pp. 777-796.

Eisenhardt, K.M. (1989), "Building theories from case study research", Academy of Management Review, Vol. 14 No. 4, pp. 532-550.

Eisenhardt, K.M. and Graebner, M.E. (2007), "Theory building from cases: Opportunities and challenges", Academy of Management Journal, Vol. 50 No. 1, pp. 25-32.

Eisenhardt, K.M. and Schoonhoven, C.B. (1990), "Organizational growth: Linking founding team, strategy, environment, and growth among U.S. semiconductor ventures, 19781988", Administrative Science Quarterly, Vol. 35 No. 3, pp. 504-529. 
Flyvbjerg, B. (2011), "Case study", in: Denzin, N. K. and Lincoln, Y. S. (Eds.), The Sage handbook of qualitative research, 4th ed, Sage, Thousand Oaks, CA, pp. 301-316.

Folta, T.B., Delmar, F. and Wennberg, K. (2010), "Hybrid entrepreneurship", Management Science, Vol. 56 No. 2, pp. 253-269.

Forsyth, D.R. (2010), Group dynamics, Wadsworth, Cengage Learning, Belmont, CA.

Francis, D.H. and Sandberg, W.R. (2000), "Friendship within entrepreneurial teams and its association with team and venture performance", Entrepreneurship Theory and Practice, Vol. 25 No. 2, pp. 5-26.

Germak, A.J. and Robinson, J.A. (2013), "Exploring the motivation of nascent social entrepreneurs", Journal of Social Entrepreneurship, Vol. 5 No. 1, pp. 5-21.

Gui, B. (1991), "The economic rationale for the "Third sector"", Annals of Public and Cooperative Economics, Vol. 62 No. 4, pp. 551-572.

Heiskala, R. (2007), "Social innovations: Structural and power perspectives", in: Hämäläinen, T. J. and Heiskala, R. (Eds.), Social Innovations, Institutional Change and Economic Performance, Edward Elgar, Cheltenham, pp. 52-79.

Huarng, K.-H. and Yu, T.H.-K. (2011), "Entrepreneurship, process innovation and value creation by a non-profit SME", Management Decision, Vol. 49 No. 2, pp. 284-296.

Jay, J. (2013), "Navigating paradox as a mechanism of change and innovation in hybrid organizations", Academy of Management Journal, Vol. 56 No. 1, pp. 137-159.

Jones, M.B. (2007), "The multiple sources of mission drift", Nonprofit and Voluntary Sector Quarterly, Vol. 36 No. 2, pp. 299-307.

Lawrence, T.B., Dover, G. and Gallagher, B. (2014), "Managing social innovation", in: Dogson, M., Gann, D. M. and Phillips, N. (Eds.), The Oxford handbook of innovation management, Oxford University Press, Oxford, pp. 316-334.

Lettice, F. and Parekh, M. (2010), "The social innovation process: Themes, challenges and implications for practice", International Journal of Technology Management, Vol. 51 No. 1, pp. 139-158.

Lewis, M.W. and Smith, W.K. (2014), "Paradox as a metatheoretical perspective: Sharpening the focus and widening the scope", Journal of Applied Behavioral Science, Vol. 50 No. 2, pp. 127-149.

Mertens, S. (1999), "Nonprofit organisations and the social economy: Two ways of understanding the third sector", Annals of Public and Cooperative Economics, Vol. 70 No. 3, pp. 501-520.

Mertens, S. and Marée, M. (2012), "The limits of the economic value in measuring the global performance of social innovation", in: Nicholls, A. and Murdock, A. (Eds.), Social innovation: Blurring boundaries to reconfigure markets, Palgrave Macmillan, Basingstoke, pp. 114-136.

Michaud, V. (2013). "Business as a pretext? Managing social-economic tensions on a social enterprise's websites", M@n@gement, Vol. 16 No. 3, pp. 294-331.

Mulgan, G. (2006), "The process of social innovation", Innovations, Vol. 1 No. 2, pp. 145-162.

Mulgan, G. (2012), "The theoretical foundations of social innovation", in: Nicholls, A. and Murdock, A. (Eds.), Social innovation: Blurring boundaries to reconfigure markets, Palgrave Macmillan, Basingstoke, pp. 33-65.

Murray, R., Caulier-Grice, J. and Mulgan, G. (2010), The open book of social innovation, Nesta, Young Foundation, London.

Nelson, T., Nelson, D., Huybrechts, B., Dufays, F., O'shea, N. and Trasciani, G. (2016), "Emergent identity formation and the co-operative: Theory building in relation to 
alternative organizational forms", Entrepreneurship \& Regional Development, Vol. 28 No. 3-4, pp. 286-309.

Nicholls, A. and Murdock, A. (2012), "The nature of social innovation", in: Nicholls, A. and Murdock, A. (Eds.), Social innovation: Blurring boundaries to reconfigure markets, Palgrave Macmillan, Basingstoke, pp. 1-30.

Pache, A.-C. and Santos, F. (2010), "When worlds collide: The internal dynamics of organizational responses to conflicting institutional demands", Academy of Management Review, Vol. 35 No. 3, pp. 455-476.

Patton, M.Q. (2002), Qualitative research \& evaluation methods, Sage, Thousand Oaks, CA.

Perrini, F., Vurro, C. and Costanzo, L.A. (2010), "A process-based view of social entrepreneurship: From opportunity identification to scaling-up social change in the case of San Patrignano", Entrepreneurship \& Regional Development, Vol. 22 No. 6, pp. 515-534.

Phillips, W., Lee, H., Ghobadian, A., O'regan, N. and James, P. (2015), "Social innovation and social entrepreneurship: A systematic review", Group \& Organization Management, Vol. 40 No. 3, pp. 428-461.

Phills, J.A., Deiglmeier, K. and Miller, D.T. (2008), "Rediscovering social innovation", Stanford Social Innovation Review, Vol. No. Fall, pp. 34-43.

Renko, M. (2013), "Early challenges of nascent social entrepreneurs", Entrepreneurship Theory and Practice, Vol. 37 No. 5, pp. 1045-1069.

Ritchie, W.J., Young, G., Shahzad, A.M., Kolodinsky, R.W. and Melnyk, S.A. (2015), "The influence of plural organizational forms on beliefs and outcomes related to new product adoption", Management Decision, Vol. 53 No. 7, pp. 1619-1641.

Roy, K. and Karna, A. (2015), "Doing social good on a sustainable basis: competitive advantage of social businesses", Management Decision, Vol. 53 No. 6, pp. 13551374.

Smith, B.R. and Stevens, C.E. (2010), "Different types of social entrepreneurship: The role of geography and embeddedness on the measurement and scaling of social value", Entrepreneurship \& Regional Development, Vol. 22 No. 6, pp. 575-598.

Smith, W.K., Gonin, M. and Besharov, M.L. (2013), "Managing social-business tensions: A review and research agenda for social enterprises", Business Ethics Quarterly, Vol. 23 No. 3, pp. 407-442.

Smith, W.K. and Lewis, M.W. (2011), "Toward a theory of paradox: A dynamic equilibrium model of organizing", Academy of Management Review, Vol. 36 No. 2, pp. 381-403.

Stohl, C., \& Cheney, G. (2001). "Participatory processes/paradoxical practices: Communication and the dilemmas of organizational democracy", Management Communication Quarterly, Vol. 14 No. 3, pp. 349-407.

Tracey, P. and Stott, N. (2017), "Social innovation: A window on alternative ways of organizing and innovating", Innovation: Organization \& Management, Vol. 1 No. 1, pp. 51-60.

Wry, T. and York, J. (2017), "An identity-based approach to social enterprise", Academy of Management Review, Vol. 42 No. 3, pp. 437-460.

Yin, R.K. (2003), Case study research: Design and methods (3rd ed.), Sage, Thousand Oaks, CA.

Yitshaki, R. and Kropp, F. (2016), "Motivations and opportunity recognition of social entrepreneurs", Journal of Small Business Management, Vol. 54 No. 2, pp. 546-565. 
Figure 1: Overview of tensions in social entrepreneurship along social innovation process stages, based on Smith et al. (2013)

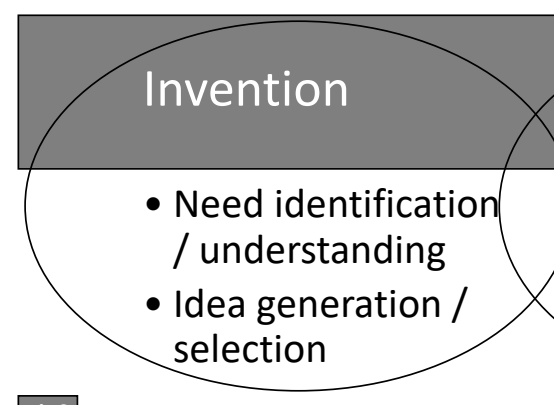

\section{Implementation Scaling/Diffusion}

Goal definition

\author{
Integration of social \\ and commercial \\ missions
}

Positioning of self with regard to social/commercial logic

Addressing the social need in the longterm and short-term
Performance metrics definition and collection Paradoxical outcomes (pervert effect)

Hiring / Socialization of employees / volunteers

Legal form selection
Divergent identity expectations from internal and external stakeholders

Sustaining initial mission while developing activity

- Idea assessment

- Prototyping

- Piloting 
Figure 2: Interest orientation of the studied cases

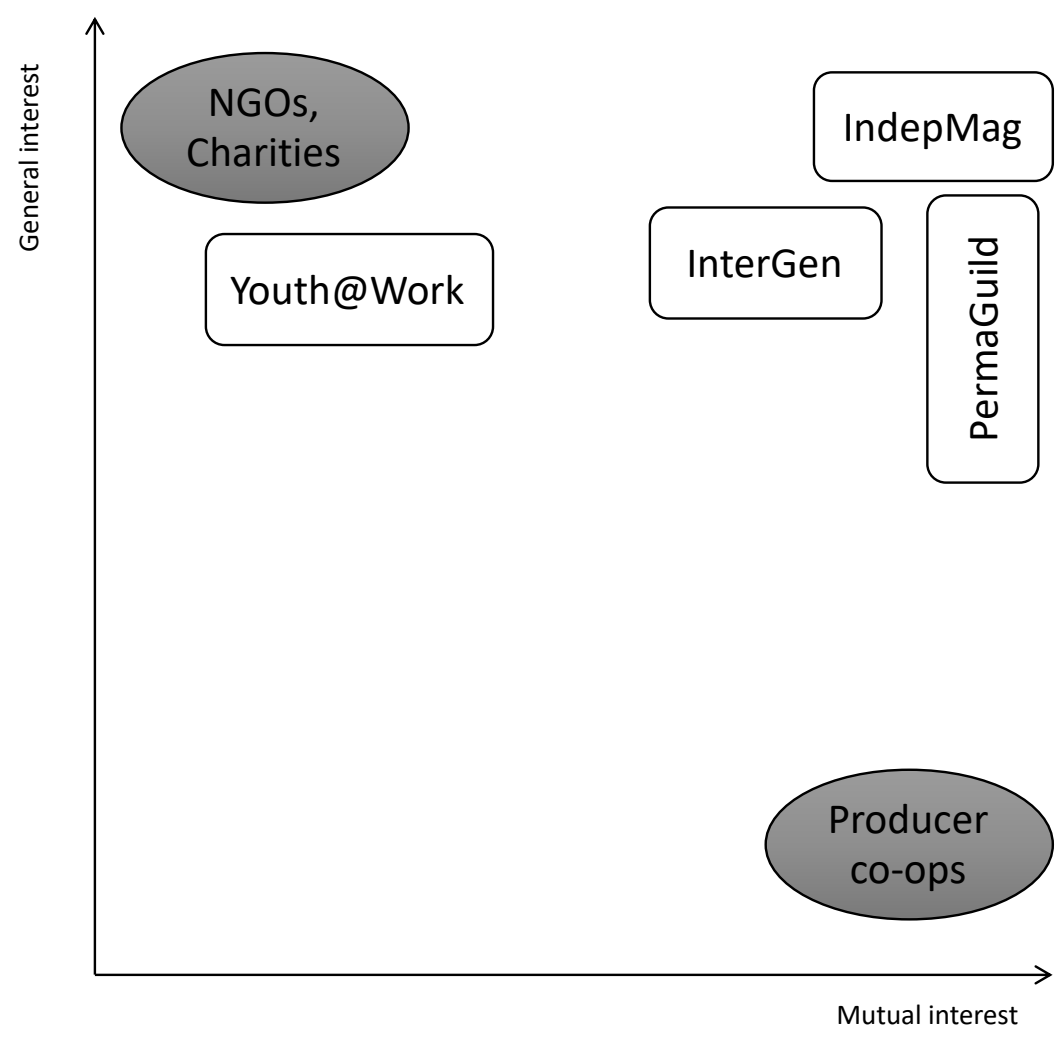

Figure 3: Drivers of tension in nascent social entrepreneurial teams

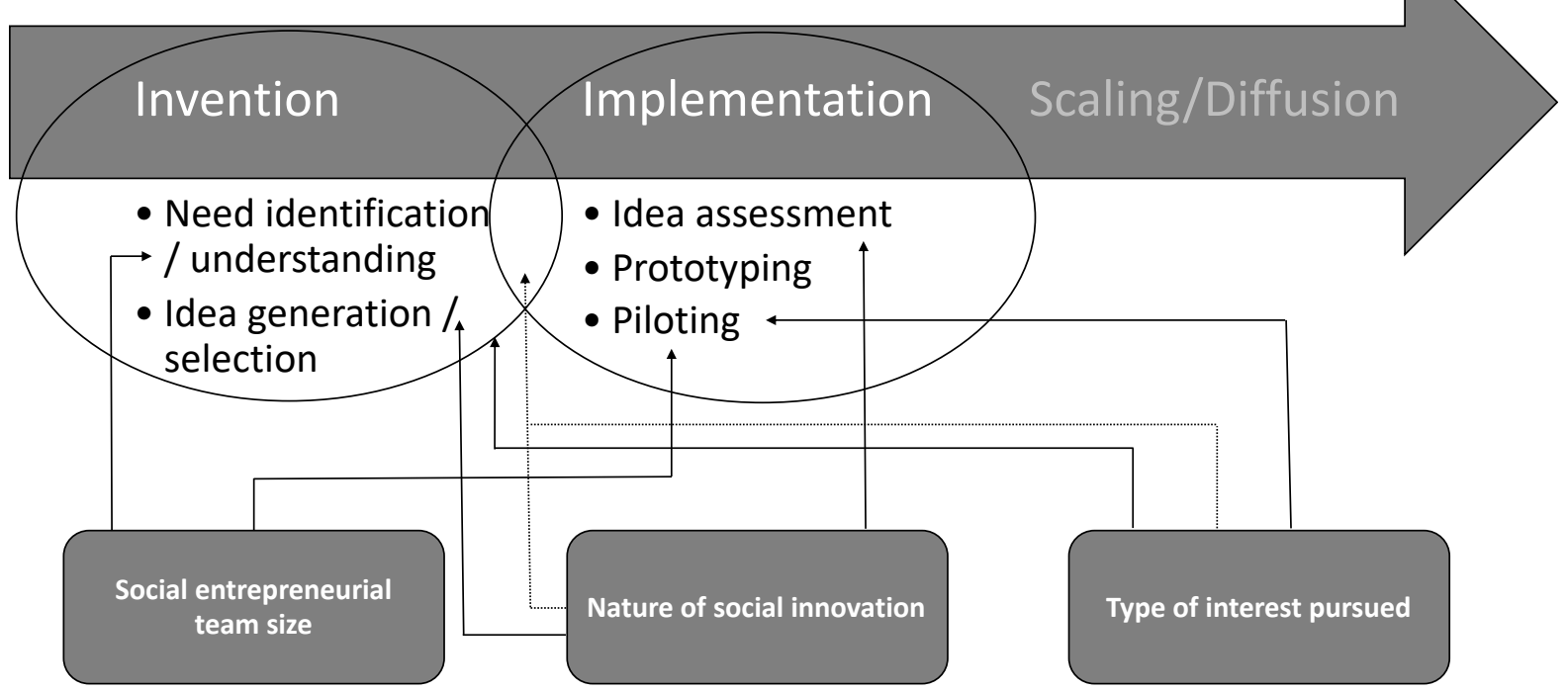


Table 1: Description of the cases

\begin{tabular}{|c|c|c|c|c|}
\hline & IndepMag (IM) & InterGen (IG) & PermaGuild (PG) & Youth@Work (YW) \\
\hline Project aim & $\begin{array}{l}\text { Creating an investigative } \\
\text { magazine that does not } \\
\text { depend financially on the } \\
\text { State (through subsidies) or } \\
\text { on any strong shareholder to } \\
\text { guarantee independence and } \\
\text { freedom of the press. } \\
\text { Stimulating slow and fair } \\
\text { press - that is, journalism } \\
\text { taking time for investigation, } \\
\text { as opposed to a 'news- } \\
\text { follower' attitude, and paying } \\
\text { a fair price for this work. }\end{array}$ & $\begin{array}{l}\text { Creating a day-care centre for } \\
\text { handicapped young adults } \\
\text { and an assisted-living facility } \\
\text { for the elderly with } \\
\text { intergenerational contacts } \\
\text { between the beneficiaries of } \\
\text { the two groups through } \\
\text { mutual help. }\end{array}$ & $\begin{array}{l}\text { Creating a social co-operative } \\
\text { to pool freelance consultants } \\
\text { that are active in one or } \\
\text { several domains relevant to } \\
\text { permaculture to offer a } \\
\text { comprehensive approach. } \\
\text { Allowing those freelance } \\
\text { consultants to enter markets } \\
\text { that they would otherwise } \\
\text { not be able to enter due to } \\
\text { the many skills and } \\
\text { knowledge needed to meet } \\
\text { the customer's needs. }\end{array}$ & $\begin{array}{l}\text { Encouraging both public and } \\
\text { private (for-profit and not- } \\
\text { for-profit) organizations to } \\
\text { improve their internship offer } \\
\text { through lobbying activities, } \\
\text { through organization } \\
\text { labelling - the criteria of } \\
\text { which were established } \\
\text { through crowdsourcing with } \\
\text { stakeholders, and through } \\
\text { coaching and consultancy } \\
\text { work. }\end{array}$ \\
\hline $\begin{array}{l}\text { Nature of social } \\
\text { innovation (outcome) }\end{array}$ & $\begin{array}{l}\text { Institutional } \\
\text { Transforming the press } \\
\text { market }\end{array}$ & $\begin{array}{l}\text { Incremental } \\
\text { New service for handicapped } \\
\text { young adults and the elderly }\end{array}$ & $\begin{array}{l}\text { Incremental } \\
\text { New service in the field of } \\
\text { permaculture }\end{array}$ & $\begin{array}{l}\text { Institutional } \\
\text { Reconfiguring the job market } \\
\text { for interns }\end{array}$ \\
\hline Entrepreneurial team & $\begin{array}{l}\text { Large } \\
\text { The team is composed of } \\
\text { nineteen members (mainly } \\
\text { journalists and graphical } \\
\text { designers), who initially } \\
\text { barely knew each other. First, } \\
\text { the invention phase was } \\
\text { initiated by around seven } \\
\text { journalists and one graphical } \\
\text { designer. They then included } \\
\text { additional journalists and } \\
\text { graphical designers in the } \\
\text { discussion. Finally, they }\end{array}$ & $\begin{array}{l}\text { Large } \\
\text { Initially, the project was } \\
\text { borne by a team of nine } \\
\text { parents of handicapped } \\
\text { teenagers. Soon, some } \\
\text { acquaintances of theirs (but } \\
\text { who did not have any } \\
\text { handicapped child) joined the } \\
\text { group. After a conflict that } \\
\text { crystallized around the } \\
\text { implementation location, the } \\
\text { team was reduced to five }\end{array}$ & $\begin{array}{l}\text { Small } \\
\text { Initially, the project was } \\
\text { borne by two people who got } \\
\text { acquainted during a training } \\
\text { event offered by one of } \\
\text { them. Prior to the } \\
\text { organization's incorporation, } \\
\text { they decided that the latter } \\
\text { would have a peripheral role } \\
\text { in the structure because she } \\
\text { wants to keep her other job, } \\
\text { whereas the former would }\end{array}$ & $\begin{array}{l}\text { Small } \\
\text { The team is composed of } \\
\text { three young adults who } \\
\text { recently experienced unpaid } \\
\text { and/or low-quality } \\
\text { internships after their } \\
\text { studies. A fourth co-founder } \\
\text { is involved in the project but } \\
\text { does not participate in the } \\
\text { daily activities and decision- } \\
\text { making. }\end{array}$ \\
\hline
\end{tabular}


included in the team people

with transversal functions

such as financial

administration and

communication. people, including three

parents) look for other full-time co-

founders. 


\section{Table 2: Respondents' profile and context of interview}

\begin{tabular}{|c|c|c|c|}
\hline Case & ID & Profile & Context of interview \\
\hline \multirow{6}{*}{ 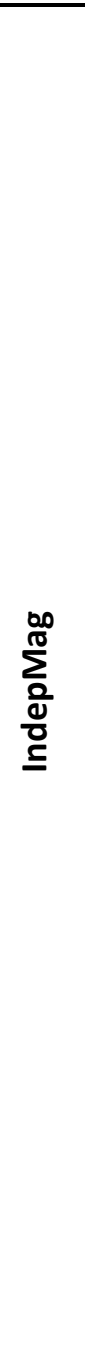 } & IM1 & $\begin{array}{l}\text { Female-Communication manager for a theatre } \\
\text { She entered the team one year after its first gathering. She is mainly responsible } \\
\text { for external relations and for planning the communication campaigns (relating to } \\
\text { the crowdfunding, then to subscriptions to the magazine). }\end{array}$ & $\begin{array}{l}\text { A couple of days before the incorporation of the } \\
\text { organization into a cooperative (invention/ early } \\
\text { implementation stages). } \\
\text { The team had just experienced a conflict about the } \\
\text { remuneration of the work done prior to first sales. }\end{array}$ \\
\hline & IM2 & $\begin{array}{l}\text { Female - Freelance journalist } \\
\text { She was present at the initial meeting organized by IM4 to discuss the state of } \\
\text { investigative journalism in Belgium and what potential solutions existed. Very } \\
\text { active in the inception phase, she acted as the chief editor of the first issue of the } \\
\text { magazine and was elected President of the cooperative's General Assembly. }\end{array}$ & $\begin{array}{l}\text { One month after incorporation of the project } \\
\text { (invention/early implementation stages). } \\
\text { IM2 was not yet designated as the head of the General } \\
\text { Assembly, nor as the leader for the first issue }\end{array}$ \\
\hline & IM3 & $\begin{array}{l}\text { Male - Freelance journalist } \\
\text { Famous award-winning investigative journalist in French-speaking Belgium, he } \\
\text { was present at the initial meeting of the project organized by IM4 and acted as } \\
\text { the co-leader for the first issue of the magazine. }\end{array}$ & $\begin{array}{l}\text { During the drafting of the first issue of the magazine } \\
\text { (implementation stage). } \\
\text { Tensions between graphical designers and journalists on } \\
\text { the consequences of using open-source software were } \\
\text { very strong. }\end{array}$ \\
\hline & IM4 & $\begin{array}{l}\text { Male - Freelance journalist } \\
\text { Famous award-winning investigative journalist in French-speaking Belgium, he is } \\
\text { considered by many team members as the tacit leader of the team. He called the } \\
\text { meeting that launched the project by initiating a discussion about investigative } \\
\text { journalists' working conditions and suggesting the creation of a magazine. }\end{array}$ & $\begin{array}{l}\text { After the first issue of the magazine and during the } \\
\text { preparation of the second issue (implementation stage). }\end{array}$ \\
\hline & IM5 & $\begin{array}{l}\text { Male - Graphical designer } \\
\text { Young graphical designer, he is the co-founder of a communication agency that } \\
\text { only works with open-source and is active in a European movement advocating } \\
\text { the growth of open-source. }\end{array}$ & $\begin{array}{l}\text { After the second issue of the magazine and during the } \\
\text { preparation of the third issue (implementation stage). }\end{array}$ \\
\hline & IM6 & $\begin{array}{l}\text { Female-Administrative worker } \\
\text { She joined the team as the first employee of the cooperative after she had acted } \\
\text { as a consultant and drafted the business and financial plans in her previous } \\
\text { position at an advising agency. She is in charge of the administrative matters } \\
\text { (logistics, finance and accounting, etc.) of the cooperative. }\end{array}$ & $\begin{array}{l}\text { After the second issue of the magazine and during the } \\
\text { preparation of the third issue (implementation stage). }\end{array}$ \\
\hline
\end{tabular}


IG1 Male-University professor

Father of a handicapped girl, married to IG4, he is recognized by the team to be its leader. He is mainly responsible for the administrative aspects (filing candidacies for grants, permit demands, etc.) and for media relations.

IG2 Female - Administrative worker

Friend of IGI and IG4, she is the godmother of their handicapped daughter. She is the main responsible team member for organizing the fundraising events.

IG3 Male - Insurance broker

Father of a handicapped girl, widowed, he is considered by the team to be the bridge-builder with external stakeholders, given his broad network. He is also responsible for fundraising events and for media relations.

IG4 Female-Museum guide

Mother of a handicapped girl, married to IG1, she is the treasurer of the project.

She takes a supporting rather than leading role in the team. The team recognizes her as the member recalling the social mission to prevent mission drift.

IG5 Male - Marketing manager, holder of the legally required diploma to manage elderly care facilities

Acquaintance of IG1, he was included in the team later on to study the feasibility of setting up jointly an elderly care facility with the care centre for handicapped. He is the financial planner of the project.

PG1 Male-Freelance webmaster/consultant

Interested by the transition movement, he undertook to travel around the world to observe initiatives and to train in permaculture. Upon return, he started to train other people in the methods he had learned abroad. He is considered and considers himself as the leader of the team because of his knowledge of permaculture.

PG2 Female - Freelance translator/consultant She met PG1 at a training event he was giving on permaculture. In the team, she is considered and considers herself as the 'midwife', helping PG1 to clarify his ideas and supporting him in creating the project. She is now also acting as a consultant in permaculture.
During inception and feasibility studies (invention stage).

The team was experiencing a major crisis around the project's aim and next steps.

During inception and feasibility studies (invention stage).

At this time, the team just split to solve the internal conflict around the aim of the project.

During negotiations for a place to build the facilities (implementation stage).

During negotiations for a place to build the facilities (implementation stage).

After the agreement for the land to build the facility (implementation phase).

Interview 1 prior to incorporation, but already some contracts - PG1 and PG2 were acting as a team of freelance consultants (invention/early implementation stages).

Interview 2 after incorporation into a cooperative (implementation stage).

Prior to incorporation, but already some contracts

(invention/early implementation stages)

At this time, she was starting to wonder about her involvement in the future of the organisation. 
YW1 Male-Full-time entrepreneur on the Youth@Work project

He completed several internships in European institutions with the hope to work there later. To ameliorate the precarious situation of interns, he initially wanted

to create a union. The meeting with YW2 triggered the turn to social entrepreneurship. He keeps an activist role in the team by lobbying externally and preventing mission drift internally.

Trained in business, he met YW1 during an internship at the European Commission and YW3 during his studies. Passionate about social entrepreneurship, he endorses the business dimension in the team. He is responsible for the implementation of the accreditation and 'labelling' of enterprises.

YW3 Male - Researcher and freelance consultant in interpersonal communication Trained in social sciences, he is interested in (social) entrepreneurship. He joined the team upon request of YW2. He is mainly responsible for the administrative aspects of the project and online communication.

Organization incorporated and the team had recently signed its first major contract (early implementation stage).

Organization incorporated and the team had recently signed its first major contract (early implementation stage).

Organization one year old and signing its sixth major contract (implementation stage).

At this time, the team hoped to generate enough cash to pay a decent salary to all team members by the end of the following year. 
Table 3: Data analysis process

\begin{tabular}{ll}
\hline Stage & Aim \\
\hline $\begin{array}{l}\text { Familiarization } \\
\text { and case } \\
\text { drafting }\end{array}$ & $\begin{array}{l}\text { Getting a holistic } \\
\text { vision of the case }\end{array}$ \\
& \\
& \\
& \\
\hline $\begin{array}{l}\text { External } \\
\text { verification of } \\
\text { the case }\end{array}$ & $\begin{array}{l}\text { Increasing } \\
\text { accuracy and } \\
\text { construct validity }\end{array}$
\end{tabular}

Stage description

Interview transcripts and secondary material were read and

re-read to get a sense of the whole story of the case. At this

stage, reflective analytical memos were drafted and kept aside. A descriptive monograph of the case was drafted, including a summary timeline around the critical events, i.e. decisive moments or turning points in the entrepreneurial process (Wright et al., 2000), that were identified by informants or by the researcher and later confirmed by the informants (see next stage).

The descriptive monograph was sent to informants to check whether any critical event was missing or if they felt there were inaccuracies in the description of the project and of the team. According to Yin (2003), this tactic increases construct validity.

Case diagnosis Identifying The material was coded following pre-established
and significant theoretically-grounded codes, this is structural coding categorization excerpts and (Saldaña, 2009) to classify excerpts according to the four highlighting loci of organizational tensions identified by Smith and Lewis manifestations of (2011): goals and outcomes; processes; identity, norms and the phenomenon values; and knowledge and time frame. Codes were not mutually exclusive, several excerpts dealing with two loci. Each of these bodies of excerpts was then recoded thematically to look for tensions by looking for linguistic cues such as tension, friction, conflict, whereas, in contrast.

\begin{tabular}{lll}
\hline Sense-making & $\begin{array}{l}\text { Explaining the } \\
\text { phenomenon in a } \\
\text { contextualized } \\
\text { way }\end{array}$ & $\begin{array}{l}\text { Each tension identified was linked back to the holistic } \\
\text { analysis in order to embed its explanation in the context of } \\
\text { the case. By so doing, the aim was to make sense of the } \\
\text { identified tensions both taken together and taken apart. }\end{array}$ \\
\hline $\begin{array}{l}\text { Cross-case } \\
\text { analysis }\end{array}$ & $\begin{array}{l}\text { Looking for } \\
\text { patterns of } \\
\text { similarities and } \\
\text { differences }\end{array}$ & $\begin{array}{l}\text { Cross-case comparisons of tensions were conducted } \\
\text { according to a 2x2 matrix (Yin, 2003, Eisenhardt, 1989) } \\
\text { along the dimensions used for theoretical sampling, i.e. } \\
\text { entrepreneurial team size and social innovation nature. } \\
\text { Within-group similarities were looked for; coupled with } \\
\text { intergroup difference. To avoid missing other dimensions } \\
\text { that could prove relevant, a final open cross-case analysis }\end{array}$ \\
& & $\begin{array}{l}\text { was conducted, looking for patterns of relationships } \\
\text { between tension types and cases. }\end{array}$ \\
\hline $\begin{array}{l}\text { Theoretical } \\
\text { abstraction }\end{array}$ & $\begin{array}{l}\text { Formulating } \\
\text { tentative causal } \\
\text { explanations of } \\
\text { the phenomenon }\end{array}$ & $\begin{array}{l}\text { Nascent theoretical propositions were written up from the } \\
\text { data, without making use of extant literature but the } \\
\text { adopted theoretical framework of Smith and Lewis (2011). } \\
\text { This allowed the data 'to speak for itself'. }\end{array}$ \\
\hline $\begin{array}{l}\text { Literature } \\
\text { enfolding }\end{array}$ & $\begin{array}{l}\text { Getting to higher } \\
\text { theoretical levels } \\
\text { and increasing } \\
\text { internal validity }\end{array}$ & $\begin{array}{l}\text { Theoretical propositions developed at the preceding stage } \\
\text { were confronted to extant literature in order to reach } \\
\text { higher theoretical levels and to gain in internal validity } \\
\text { (Eisenhardt, 1989). }\end{array}$ \\
\hline
\end{tabular}


